Sains Peternakan Vol. 14 (2), September 2016: 50-56

ISSN 1693-8828

\title{
Pengaruh Suplementasi Probiotik dalam Ransum Terhadap Kualitas Fisik Daging Itik
}

\author{
Dyah Wahyuni ${ }^{1}$, Sofi Arisuteja ${ }^{2}$, Sofia Sandi ${ }^{1}$ dan Fitra Yosi ${ }^{1}$ \\ ${ }^{1}$ Program Studi Peternakan, Universitas Sriwijaya \\ Jl. Raya Palembang-Prabumulih KM. 36 Indralaya, Ogan Ilir, Sumatera Selatan \\ ${ }^{2}$ Alumni Program Studi Peternakan Universitas Sriwijaya \\ Contact person: \\ Dyah Wahyuni, S.Pt., M.Sc. \\ Program Studi Peternakan, Universitas Sriwijaya \\ Jl. Raya Palembang-Prabumulih KM. 36 Indralaya, Ogan Ilir, Sumatera Selatan \\ Email:dyahwahyuni18@gmail.com
}

\begin{abstract}
ABSTRAK
Penelitian ini bertujuan untuk mengetahui pengaruh suplementasi probiotik dalam ransum terhadap kualitas fisik ( $\mathrm{pH}$, daya ikat air, susut masak dan keempukan) daging itik. Materi yang digunakan adalah itik lokal yang disuplementasi probiotik. Metode penelitian yang digunakan adalah Rancangan Acak Lengkap (RAL) yang terdiri dari 7 perlakuan dan 4 ulangan, yaitu P1 (ransum basal/kontrol), P2 (ransum basal+probiotik), P3 (ransum basal+infeksi E.coli), P4 (ransum basal+infeksi Salmonella), P5 (ransum basal+probiotik+infeksi E.coli), P6 (ransum basal+probiotik+infeksi Salmonella) dan P7 (ransum basal+probiotik+infeksi E.coli+infeksi Salmonella). Hasil penelitian menunjukkan bahwa suplementasi probiotik sebanyak $10^{6} \mathrm{cfu} / \mathrm{ml}$ dalam ransum tidak mempengaruhi kualitas fisik $(\mathrm{pH}$, daya ikat air, susut masak dan keempukan) daging itik.
\end{abstract}

Kata kunci: probiotik, ransum, kualitas fisik, daging, itik

\section{The Effect of Probiotic In Ration on Physical Quality of Duck Meat}

\begin{abstract}
This research aim to find out the effect of probiotic in ration on physical quality ( $\mathrm{pH}$, water holding capacity, cooking loss and tenderness) of duck meat. The materials used was local duck supplemented probiotic into ration. Research's method used was Completely Randomize Design (CRD) consisted of 7 treatments and 4 replications namely P1(basic ration/ control), P2 (basic ration+probiotic), P3 (basic ration + infected by E.coli), P4 (basic ration+infected by Salmonella), P5 (basic ration+probiotic +infected by E.coli), P6 (basic ration+ probiotic+infected by Salmonella) and P7 (basic ration+probiotic+infected by E.coli+Infected by Salmonella). The results showed that probiotic suplementation about $10^{6} \mathrm{cfu} / \mathrm{ml}$ into ration were no significantly effect on physical quality ( $\mathrm{pH}$, water holding capacity, cooking loss and tenderness) of duck meat.
\end{abstract}

Keywords: probiotic, ration, physical quality, meat, duck 


\section{PENDAHULUAN}

Probiotik adalah mikroorganisme hidup yang ditambahkan dalam pakan ternak dengan tujuan untuk meningkatkan keseimbangan mikroflora usus yang apabila dikonsumsi dalam jumlah yang sesuai akan mengoptimalkan penyerapan sari-sari makanan (Kusumawati, 2003). Keberadaan probiotik di dalam usus berperan sebagai bakteriosin dan menghasilkan asam laktat yang memberikan efek antagonis terhadap bakteri patogen. Asam laktat yang dihasilkan akan menurunkan $\mathrm{pH}$ yang menghambat pertumbuhan bakteri patogen. Jumlah bakteri patogen yang menurun akan menyebabkan meningkatnya jumlah bateri baik di dalam usus sehingga kesehatan ternak dapat meningkat (Purwati dan Syukur, 2006).

Manfaat probiotik untuk ternak tidak hanya sebatas menjaga kesehatan saluran pencernaan saja, namun juga dapat mengendalikan infeksi bakteri seperti Salmonella yang bisa menular pada manusia (Manin et al., 2003). Pemberian probiotik juga bermanfaat sebagai bahan aditif alami pengganti antibiotik, sehingga daging yang dihasilkan menjadi lebih sehat karena bebas dari residu antibiotik. Suplementasi probiotik ke dalam pakan ternak itik meningkatkan produksi daging dengan kandar lemak yang rendah. Hal ini dikarenakan probiotik menghasilkan asam laktat yang mampu menurunkan kadar trigliserida sehingga kadar lemak menurun (Saputri, 2012). Kandungan lemak yang rendah akan mempertahankan $\mathrm{pH}$ daging itik tetap dalam kondisi yang baik dan normal yaitu 5,10 hingga 6,10 (Edward et al., 1978).

Hasil penelitian dan publikasi mengenai manfaat probiotik terhadap performa dan kesehatan ternak itik telah banyak dilakukan, namun terhadap kualitas daging masih sangat terbatas. Berdasarkan hal tersebut maka perlu dilakukan penelitian mengenai pengaruh suplementasi probiotik dalam ransum terhadap kualitas fisik daging itik.

\section{MATERI DAN METODE}

\section{Materi Penelitian}

\section{Ternak Itik}

Itik yang digunakan adalah itik lokal yang berumur 3 bulan sebanyak 56 ekor yang diperoleh dari Kabupaten Ogan Ilir, Sumatra Selatan.

\section{Kandang}

Kandang yang digunakan adalah kandang baterai sebanyak 28 petak. Tiap petak berukuran $75 \times 50 \times 40 \mathrm{~cm}$, diisi 2 ekor itik lokal dan ditempatkan 1 tempat pakan dan 1 tempat minum.

\section{Peralatan}

Peralatan yang digunakan adalah cuter, cawan, gelas piala, kertas label, kertas saring, kertas millimeter blok, pisau, plastik, timbangan digital, tali plastik, oven, $\mathrm{pH}$ meter dan water bath.

\section{Ransum}

Ransum yang digunakan adalah ransum basal yang terdiri dari tepung jagung, dedak padi, bungkil kedelai, minyak sayur, premix, metionin dan lisin. Komposisi dan kandungan nutrisi ransum disajikan dalam Tabel 1. dan 2. berikut. 
Tabel 1. Susunan Ransum Perlakuan Itik Fase Grower (8-20 minggu)

\begin{tabular}{ll}
\hline Jenis Bahan Baku & Jumlah $(\%)$ \\
\hline Jagung & 64,00 \\
Bungkil Kedelai & 21,25 \\
Dedak & 10,00 \\
Minyak Sayur & 3,00 \\
Lisin & 0,50 \\
Metionin & 0,50 \\
Premix & 0,75 \\
\hline Total & 100,00 \\
\hline
\end{tabular}

Tabel 2. Kandungan Nutrisi Ransum Perlakuan

\begin{tabular}{ll}
\hline Kandungan Nutrisi & Jumlah $(\%)$ \\
\hline Protein kasar & 19,75 \\
Serat kasar & 5,35 \\
Lemak kasar & 3,71 \\
Kalsium & 0,72 \\
Phosphor & 0,47 \\
Energi metabolis $(\mathrm{kkal} / \mathrm{kg})$ & 2913 \\
\hline
\end{tabular}

Sumber: Hasil analisa proksimat laboratorium Nutrisi dan Makanan Ternak Program Studi Peternakan Fakultas Pertanian Universitas Sriwijaya (2014).

\section{Probiotik silase ransum komplit}

Probiotik yang digunakan berasal dari hasil isolasi silase ransum komplit.

\section{Metode Penelitian}

Metode penelitian yang digunakan adalah Rancangan Acak Lengkap (RAL) yang terdiri dari 7 perlakuan dan 4 ulangan. Setiap ulangan terdiri dari 2 ekor itik lokal sebagai satuan peubah. Perlakuan yang diberikan adalah sebagai berikut :

$\mathrm{P} 1=$ Ransum basal (kontrol)

$\mathrm{P} 2=$ Ransum basal+probiotik

P3 = Ransum basal+infeksi E.coli

P4 = Ransum basal+ infeksi Salmonella

P5 = Ransum basal+probiotik+infeksi E.coli

$\mathrm{P} 6=$ Ransum basal+probiotik+infeksi Salmonella

P7 = Ransum basal+probiotik+infeksi E.coli + infeksi Salmonella

\section{Pelaksanaan Penelitian}

\section{Persiapan Kandang}

Kandang itik yang akan digunakan dibersihkan dan dikapur secara merata dan disucihamakan menggunakan disinfektan. Pengapuran bertujuan untuk mengurangi kelembaban dan mencegah tumbuhnya jamur. Tempat pakan, tempat air minum dan perlengkapan kandang lainnya dicuci bersih. Kandang yang sudah disucihamakan dibiarkan selama satu sampai dua minggu. Masingmasing petak diberi nomor perlakuan dan ulangan untuk mempermudah pencatatan.

\section{Pemeliharaan Ternak}

Itik lokal ditimbang dan dilakukan pengacakan berdasarkan bobot badan awal. Itik diberi ransum perlakuan dilakukan sedikit demi sedikit dengan tujuan agar itik tersebut 
mengenal ransum perlakuan. Pemberian perlakuan probiotik silase ransum komplit cair pada minggu pertama sampai minggu kedua pemeliharaan diberikan setiap hari sebanyak 1 $\mathrm{ml}$ (pengenceran $10^{6}$ ) per ekor pada perlakuan P2, P5, P6 dan P7 dengan cara oral, pada minggu ke-tiga diberikan probiotik kapsulasi dengan kandungan $10^{6}$ sebanyak 0,5 gram per ekor pada perlakuan P2, P5, P6 dan P7 dengan cara oral. Minggu ke-empat itik diberikan infeksi bakteri patogen yaitu E.coli sebanyak $1 \mathrm{ml}$ per ekor pada perlakuan P3, P5 dan P7 sebanyak 1 kali dan infeksi bakteri patogen yaitu Salmonella sebanyak $1 \mathrm{ml}$ per ekor pada perlakuan P4, P6 dan P7 sebanyak 1 kali, kemudian sampai minggu ke-tujuh diberikan probiotik silase ransum komplit cair setiap hari dengan cara mencampurkan kedalam pakan sebanyak $10 \mathrm{ml}$ per ekor pada perlakuan P2, P5, P6 dan P7 dengan pengenceran $10^{6}$. Selama pemeliharaan, ransum dan air minum diberikan tiga kali yaitu pagi hari, siang hari dan sore hari, ransum diberikan secara ad libitum. Pemeliharan dilakukan selama 3 bulan.

\section{Pengambilan sampel}

Itik yang telah dipelihara pada penelitian ini kemudian disembelih dan diambil bagian otot dada. Berat sampel yang diambil sesuai dengan keperluan parameter yang akan diuji.

\section{Peubah yang Diamati}

Nilai pH

Pengujian $\mathrm{pH}$ dilakukan dengan menggunakan metode Bouton et al. (1971) dalam Soeparno (2005). Sampel seberat $10 \mathrm{~g}$ dihaluskan kemudian dilarutkan ke dalam 10 $\mathrm{ml}$ aquades hingga homogen dan kemudian diukur dengan $\mathrm{pH}$ meter. Pengukuran dilakukan tiga kali dan hasilnya dirata-rata sebagai nilai $\mathrm{pH}$ daging.

\section{Daya Ikat Air}

Metode yang digunakan adalah metode Hamm (Soeparno, 2005). Daging seberat 0,3 gram diletakan diatas plat kaca, dialasi dengan kertas saring, dan diberi beban $35 \mathrm{~kg}$ selama 5 menit. Area basah yang terbentuk dihitung (luas area basah).

$$
\begin{aligned}
& \text { Area Basah }=(a-b) \\
& \mathrm{Mg} \mathrm{H}_{2} \mathrm{O} \\
& =\frac{\text { area basah }}{0,0984}-8,0 \\
& \text { Daya Ikat Air } \\
& =\% \text { Kadar air } \\
& =\frac{\left(\mathrm{MgH}_{2} \mathrm{O}\right)}{300} \times 100 \%
\end{aligned}
$$

\section{Susut Masak (Soeparno, 2005)}

Persentase susut masak atau berat yang hilang selama pemasakan dapat hitung dengan rumus:

$$
\text { Susut Masak }=\frac{\text { berat sebelum dimasak }- \text { berat setelah dimasak }}{\text { berat sebelum dimasak }} \times 100 \%
$$

\section{Keempukan Daging}

Pengujian keempukan daging diukur menggunakan alat texture analyzer merek Probe Field. Sampel daging diletakkan tepat di bawah probe silinder, kemudian jarum dikaitkan pada ujung sampel. Probe tipe silinder akan menekan bagian tengah sampel sehingga sampel akan terputus dan akan ada angka yang tertera pada alat texture analyzer. Angka yang tertera pada alat merupakan hasil 
pengukuran yang merupakan nilai keempukan daging (Farida et al., 2006).

\section{Analisa Data}

Data hasil pengamatan dianalisis dengan Anova. Apabila hasil yang diperoleh berpengaruh nyata, maka dilakukan uji lanjut dengan menggunakan Uji Jarak Berganda Duncan (Steel dan Torrie, 1993).

\section{HASIL DAN PEMBAHASAN}

Data hasil analisis statistik terhadap $\mathrm{pH}$, daya ikat air, susut masak dan keempukan daging itik yang diberi ransum dengan suplementasi probiotik dapat dilihat pada Tabel 3 berikut:

Tabel 3. Pengaruh Suplememntasi Probiotik dalam Ransum Terhadap pH, Daya Ikat Air, Susut Masak dan Keempukan Daging Itik

\begin{tabular}{lllll}
\hline \multirow{2}{*}{ Perlakuan } & Rataan & & & \\
\cline { 2 - 5 } & pH daging & Daya Ikat Air $(\%)$ & Susut Masak(\%) & Keempukan(gf) \\
\hline P1 & $6,08 \pm 0,22$ & $69,58 \pm 2,21$ & $23,09 \pm 3,77$ & $206,45 \pm 4,00$ \\
P2 & $5,80 \pm 0,36$ & $73,37 \pm 2,01$ & $19,65 \pm 5,35$ & $145,30 \pm 1,99$ \\
P3 & $6,13 \pm 0,32$ & $71,83 \pm 3,26$ & $21,42 \pm 3,05$ & $255,90 \pm 4,32$ \\
P4 & $6,23 \pm 0,05$ & $70,54 \pm 2,11$ & $21,46 \pm 2,41$ & $273,65 \pm 3,36$ \\
P5 & $5,83 \pm 0,39$ & $68,79 \pm 4,91$ & $21,71 \pm 2,55$ & $182,35 \pm 2,96$ \\
P6 & $5,88 \pm 0,13$ & $71,61 \pm 3,11$ & $20,61 \pm 4,45$ & $235,95 \pm 3,76$ \\
P7 & $6,23 \pm 0,22$ & $71,61 \pm 2,06$ & $23,67 \pm 2,95$ & $238,28 \pm 3,60$ \\
\hline
\end{tabular}

Ket: P1 (Ransum kontrol), P2 (Ransum basal + probiotik), P3 (Ransum basal + infeksi E.coli), P4 (Ransum basal + infeksi Salmonella), P5 (Ransum basal + probiotik + infeksi E.coli), P6 (Ransum basal + probiotik + infeksi Salmonella), P7 (Ransum basal + probiotik + infeksi E.coli + infeksi Salmonella)

\section{Nilai pH Daging}

Berdasarkan Tabel 3. diatas dapat diketahui bahwa pemberian probiotik tidak berpengaruh nyata terhadap nilai $\mathrm{pH}$ daging itik dan masih berada dalam kisaran $\mathrm{pH}$ normal daging. Ini mengindikasikan bahwa penambahan probiotik sebesar $10^{6} \mathrm{cfu} / \mathrm{ml}$ dalam ransum hanya mampu meningkatkan kerja sistem pencernaan dengan menghambat petumbuhan bakteri patogen saja. Sesuai hasil penelitian Wiryawan (2003) yang melaporkan bahwa probiotik dapat berperan dalam membantu mengoptimalkan fungsi saluran pencernaan untuk mencerna dan menyerap nutrisi pakan. Semakin tinggi konsentrasi probiotik yang diberikan maka penyerapan nutrisi akan meningkat sehingga nilai $\mathrm{pH}$ daging cenderung menurun (Dewi, 2015).

Rataan $\mathrm{pH}$ daging itik pada penelitian ini adalah 5,80-6,23 tidak jauh berbeda dengan hasil penelitian Huda et al. (2011) yang menyatakan bahwa $\mathrm{pH}$ daging itik peking dan entok yang berkisar 5,93-6,01 masih berada dalam kisaran $\mathrm{pH}$ normal daging. Menurut Edward et al. (1978) daging yang mempunyai $\mathrm{pH}$ normal kisaran antara 5,10-6,10 mempunyai struktur jaringan otot yang terbuka dan warna yang cerah dan aroma yang khas sehingga layak dikonsumsi.

\section{Daya Ikat Air (DIA)}

Pemberian ransum dengan suplementasi probiotik menunjukkan tidak 
berpengaruh nyata terhadap daya ikat air daging itik. Hasil ini sesuai dengan penelitian Belawa (2004) yang menyatakan bahwa suplementasi probiotik Lactobacillus kompleks dalam ransum dapat meningkatkan daya ikat air daging itik afkir walaupun secara statistik tidak berpengaruh nyata. Nilai $\mathrm{pH}$ yang tidak berpengaruh nyata juga mempengaruhi nilai daya ikat air menjadi tidak berpengaruh nyata (Soeparno 2005 dan Alvarado et al., 2007).

\section{Susut Masak (Cooking Loss)}

Suplementasi probiotik pada penelitian ini tidak berpengaruh nyata terhadap susut masak daging itik. Nilai susut masak daging berbanding terbalik dengan nilai daya ikat air pada daging tersebut. Soeparno (2005) menyatakan jika daya ikat air daging meningkat maka susut masak daging akan turun. Daging dengan susut masak yang lebih rendah mempunyai kualitas yang relatif lebih baik dibandingkan dengan daging yang memiliki nilai susut masak yang lebih besar, karena kehilangan nutrisi selama pemasakan menjadi akan lebih sedikit (Mulyati, 2003).

Nilai susut yang tidak berpengaruh nyata ini diduga disebabkan karena nilai $\mathrm{pH}$ dan daya ikat air yang juga tidak berpengaruh nyata. Menurut Lawrie (2003) daya mengikat air daging mempengaruhi susut masak daging, apabila daya mengikat air meningkat maka akan mengurangi penyusutan daging selama dimasak.

\section{Keempukan daging}

Keempukan dinyatakan dalam satuan gf (gram force) yang merupakan gaya maksimum yang dibutuhkan untuk memberikan tekanan atau menghancurkan daging dengan beban tertentu. Dalam hal ini, semakin tinggi nilai keempukan daging (gf), maka akan semakin keras daging tersebut. Berdasarkan data analisis statistik pada Tabel 3. dapat diketahui bahwa suplementasi probiotik dalam ransum tidak berpengaruh nyata terhadap keempukan daging itik. Rataan nilai keempukan yang diberikan probiotik silase ransum komplit ini berkisar antara $145,30 \mathrm{~N}-273,65 \mathrm{~N}$. Nilai keempukan daging itik yang disuplementasi probiotik relatif sama dengan kontrol. Artinya, suplementasi probiotik tidak mempengaruhi keempukan daging.

\section{KESIMPULAN}

Suplementasi probiotik sebanyak $10^{6}$ $\mathrm{cfu} / \mathrm{ml}$ dalam ransum itik tidak mempengaruhi kualitas fisik $(\mathrm{pH}$, daya ikat air, susut masak dan keempukan) daging.

\section{DAFTAR PUSTAKA}

Alvarado C and McKee S. 2007. Marination to improve functional properties and safety of poultry meat. Journal Appl Poultry. Res. 16: 113-120.

Belawa Y.T.G. 2004. Pengaruh suplementasi laktobasilus komplek dalam ransum yang mengandung daun pepaya terhadap berat dan kualitas karkas beserta produksi daging giblet pada itik afkir. Seminar Nasional Teknologi Peternakan dan Veterainer. Udayana. Bali.

Dewi K. 2015. Pengaruh pemberian probiotik dan tepung kunyit dalam ransum terhadap $\mathrm{pH}$, warna dan aroma daging itik pegagan. Skripsi. Fakultas Pertanian, Universitas Sriwijaya.

Edward R.A., Fleet G.H. and Woottoon M. 1978. Foodcommodity science. In: K.A. Buckle, R.A. Edward, G.H. Fleet and M. Wooton (Eds.). Acourse manual in food science. Australian Vicechancellors Committee. Watson Ferguson and Co. Brisbane.

Farida D.N., Kusumaningrum H.D., Wulandari N dan Indrasti D. 2006. Analisa laboratorium. Departemen ilmu dan teknologi pangan IPB. Bogor. 
Huda N.P and Ahmad A.A.R. 2011. Proximat and physicochemical properties of peking and Muscovy duck breasts and thighs for further processing. J. Food Agric. Environt. Vol. 9: 82-88.

Kusumawati N, Bettysri L.J, Siswa S, Ratihdewanti dan Hariadi. 2003. Seleksi Bakteri Asam Laktat Indigenous sebagai Galur Probiotik dengan Kemampuan Menurunkan Kolesterol. Journal Mikrobiologi Indonesia. Vol. 8(2): 39-43.

Lawrie R.A. 2003. Meat sciences. The $6^{\text {th }}$ ed. Terjemahan. A. Paraksi dan A. Yhuda. Universitas Indonesia Press. Jakarta.

Manin F, Ella H, Yusrizal and Nurhayati. 2005. Effect of Kerinci Duck's Intestinal Probiotic (Bacillus circulans and Bacillus sp) as Feed Addtive on Broiler Performans. Proceedings of The $4^{\text {th }}$ ISTAP "Animal Production and Sustanable Agriculture in The Tropics" Faculty of Animal Sience, Gajah mada Uniersity. November 8-9, 2006. p: 276-286.

Mulyati. 2003. Pengaruh Penggunaan Bungkil Biji Karet Yang Di Fermentasi dengan
Ragi Tempe dan Oncom Terhadap Kualitas Daging Ayam Broiler (Thesis). Pasca Sarjana Universitas Diponegoro. Malang.

Purwati E. dan Syukur S. 2006. Peranan pangan probiotik untuk mikroba Patogen dan kesehatan. Dipresentasikan pada Dharma Wanita Persatuan Propinsi Sumatera Barat, Padang, 8 Agustus 2006.

Saputri F. 2012. Pengaruh pemberian probiotik bakteri asam laktat (BAL) Pediococcus pentosaceus terhadap keseimbangan mikroflora usus dan trigliserida daging Itik Pitalah. Skripsi. Universitas Andalas. Padang.

Steel R.G.D dan Torrie J.H. 1993. Prinsip dan Prosedur Statistika. Suatu pendekatan biometric. PT. Gramedia Utama: Jakarta.

Soeparno. 2005. Ilmu dan Teknologi Daging. Gadjah Mada University Press, Yogyakarta.

Wiryawan A. 2003. Fungsi Probiotik Terhadap Dunia Peternakan. Gajah MadaUniversity Press. Yogyakarta. 